\title{
Perceptions of L1 Use as a Pre-listening Activity Relative to L2 Proficiency
}

\author{
Kei Mihara ${ }^{1}$ \\ ${ }^{1}$ Faculty of Science and Engineering, Kindai University, Osaka, Japan \\ Correspondence: Kei Mihara, Faculty of Science and Engineering, Kindai University, Osaka, 577-8502, Japan. \\ Tel: 81-6-6721-2332. E-mail: k.mihara358@gmail.com
}

Received: December 31, 2016 Accepted: January 27, 2017 Online Published: February 9, 2017

doi:10.5539/ijel.v7n3p1 URL: http://dx.doi.org/10.5539/ijel.v7n3p1

\begin{abstract}
The purpose of this study is to examine students' perceptions of L1 translations when learning L2 vocabulary as a pre-listening activity and to investigate their listening comprehension test performance. Higher and lower level Japanese university students were required to learn vocabulary as a pre-listening activity. Both levels were divided into two groups. One group was asked to learn vocabulary items using L1 translations, whereas the other used L2 definitions. Previous research has suggested that using L1 translations is preferable for lower level students. However, the results of the present study contradict the findings of previous studies. The present study shows that both higher and lower level students tended to prefer L2 definitions when learning L2 vocabulary, and that this tendency was stronger among lower level students. Moreover, regarding listening comprehension test performance, the results show that higher level students who used L1 translations consistently outperformed those who used L2 definitions, although lower level students did not show such consistency.
\end{abstract}

Keywords: L1 translations, L2 definitions, listening comprehension, pre-listening activities, students' perceptions, vocabulary learning

\section{Introduction}

\subsection{Introduction of the Study}

This study examines students' perceptions of L1 use in the EFL classroom. Japan is a largely monolingual society in which nearly all students are native speakers of Japanese. Consequently, there have been ongoing debates concerning whether or not teachers should use their students' L1 in EFL classrooms. This study investigated students' perceptions of L1 use as they completed a listening comprehension test. I began by examining the listening test results to determine whether L1 use was a more effective learning mode for participants when compared to L2 use alone. I then administered a questionnaire to determine participants' preferences for L1 or L2 use in vocabulary learning.

\subsection{Literature Review}

There are a variety of commonly used second or foreign language teaching approaches and methods, especially for teaching new vocabulary items. Various studies have examined the effectiveness of students using their L1s and the rationales for doing so, in addition to the positive aspects of L2 use alone and its impact on students. Generally, previous research shows that L1 use by learners is more effective and less laborious for both students and teachers (Afzai, 2013; Al-balawi, 2016; Soulignavong \& Souvannasy, 2009). Shuchi and Islam (2016) suggested that "a judicious and moderate use of L1 does not hinder learning; rather, it assists, aids and facilitates the teaching and learning process thus providing the teacher with an effective pedagogical tool for maximizing the learning outcomes" (p. 62). This teaching method (i.e., the bilingual approach) is an efficient strategy, particularly when students have low English proficiencies. However, other studies are supportive of L2 use alone (i.e., the monolingual approach), which is an appropriate teaching strategy when students are heterogeneous in terms of their language backgrounds.

The main reason for supporting a monolingual approach is that it provides L2 exposure (Ellis, 2005; Turnbull, 2001); students have many more opportunities for L2 exposure if their teacher adopts a monolingual approach. In addition, an excessive use of L1 also "could have a de-motivating effect on students" (Mahmoudi \& Amirkhiz, 2011, p. 135). On the other hand, the principal reason for supporting a bilingual approach is that L1 use 
facilitates comprehension, particularly when students are learning the meanings of unknown words (Cook, 2001; Joyce, 2015; Liao, 2006; Liu, 2008; Nation, 2003). Using L1 translations to explain the meaning of a word is a "time-saving device" (Harbord, 1992, p. 353) and also an "attractive short cut" when teachers have an L1 in common with their students (Alroe \& Reinders, 2015, p. 54). Although Alroe and Reinders (2015) did not support Prince's (1996) contention that L1 use is a good strategy for learning new vocabulary, it is generally considered beneficial in facilitating students' vocabulary learning. In fact, Afzal (2013) argued that "limited and judicious use of the mother tongue in the English classroom does not reduce students' exposure to English, but rather can assist in the teaching and learning processes" (p. 1851). For example, Edstrom (2006) examined 15 false-beginner students in her university-level Spanish course, and noted that students' use of L1 (English) for a pre-listening activity might have made their L2 (Spanish) video input more salient. In fact, with the L1 pre-listening activity, the students' understanding of the video was good.

Various empirical studies have been conducted regarding pre-listening activities; some have adopted a monolingual approach and included only L2 experiments, whereas others have taken a bilingual approach and asked participants to use both their L1 and L2. If students are heterogeneous in terms of their language backgrounds, the former might be a good choice. However, in a monolingual classroom, using only an L2 might not produce positive effects with respect to students' performances and perceptions.

Chang and Read (2008) investigated four types of pre-listening activities and students' anxiety levels by adopting a bilingual approach with English and Chinese. Participants in their study included 160 university students in Taiwan. The researchers found that a vocabulary activity was more likely to result in high anxiety levels and poor performances when compared to three types of pre-listening activities. Moreover, at both higher and lower proficiency levels, students with high post-test anxiety performed poorly on the listening comprehension test. Considering Liao's (2006) finding that learning anxiety is reduced and motivation enhanced by L1 use, it is expected that students' anxiety levels will decrease and their performance improve through L1 use during a pre-listening activity. Thus, the present study compares a monolingual pre-listening approach with a bilingual one.

\section{Methodology}

\subsection{Method}

In this study, I investigate students' perceptions of using their L1 to learn L2 vocabulary prior to a listening comprehension test. Participants completed a multiple-choice listening comprehension test twice each week. They were divided into two groups: One was asked to learn the vocabulary items using their L1 (Japanese), whereas the other used only their L2 (English). Before taking each test, participants were given a list of vocabulary items from the spoken text, which was recorded as audio onto a compact disc. I analyzed the students' test scores in order to ascertain the effectiveness of using their L1 to learn L2 vocabulary. I also administered a paper-and-pencil questionnaire to gauge how participants felt about using their L1 during the pre-listening activities.

\subsection{Participants}

Participants comprised 92 first-year students aged from 18 to 20 enrolled in General English classes at a private Japanese university; all were native speakers of Japanese from the Faculty of Science and Engineering who had been learning English as a foreign language for six years or more. Each participant completed a placement test one day after beginning their university studies; five days later, they were placed into a suitable class based on the test results. These 90-minute classes were compulsory for all first-year students and held twice on a weekly basis.

I conducted experiments in each of the four classes, which varied in size between 23 and 32 students. However, not all students were willing to take part in the experiments. Thus, to equate groups of the same level, I chose 24 students from each of the higher level classes, and 22 students from each of the lower level classes. The students selected from the upper-intermediate classes (i.e., Classes 1 and 2) included 18 males and 6 females in the former, and 19 males and 5 females in the latter. Classes 3 and 4 were intermediate level; given that there were no female students available to select from Class 4, it was necessary to choose male students from Class 3 in order to create a balance with respect to gender. Fifteen minutes were allotted to the experiment at the beginning of each class.

\subsection{Materials}

Participants were asked to take a listening comprehension test once a week, three times in total. Each test contained two dialogues and two monologues. Six dialogues and six monologues were taken from the Official Guide to the New TOEIC Test, Vol. 3 without modification. Each dialogue or monologue included three 
multiple-choice questions with four separate answer options. For the Test of English for International Communication Listening and Reading (TOEIC L\&R), questions and options are written on the same sheet of paper; however, for this experiment, only the options were presented in written form, and participants were required to listen to the questions and spoken text while attempting to comprehend them. Although it would have been easier for students if the questions were supplied on the sheet, I hypothesized that differences between the four groups would be more evident if only the options were presented in written form.

\subsection{Procedure}

Two types of pre-listening activities were compared in this study. One utilized a bilingual approach, whereby students were instructed to memorize vocabulary items using L1 translations; the other adopted a monolingual approach, whereby participants were asked to memorize the same vocabulary items using L2 definitions. Students were then required to complete a listening comprehension test three separate times; each test contained four spoken texts comprising two dialogues and two monologues. I compiled vocabulary lists containing five keywords or phrases from each spoken text, and every test included four spoken texts; hence, each vocabulary list comprised 20 items. An example of one vocabulary list can be found in Appendix A.

For students in Classes 1 and 3, vocabulary items were listed together with their L1 translations; for those in Classes 2 and 4, vocabulary items were listed in conjunction with their L2 definitions. Each target word or phrase was presented in isolation, without a sample sentence. Before listening to each text, participants were asked to silently read five vocabulary items from the list for one minute. Next, they listened to three questions about the text. Students in Classes 1 and 3 listened to L1 translations of the questions, whereas those in Classes 2 and 4 listened to the questions only in English. I provided a verbal on-the-spot translation of each question for Classes 1 and 3; however, I did not assist Classes 2 and 4. Students next listened to the spoken text and three questions a second time, and then were asked to answer the questions.

After conducting the experiments, I analyzed the listening comprehension test results in order to identify differences between students who received L1 translations of the vocabulary items and those who received L2 definitions. In addition, through statistical analysis, I examined differences between the four classes with respect to their listening comprehension test performance.

\subsection{Research Questions}

The following research questions are posed in this study:

1) Are satisfaction levels higher among students who learn vocabulary using L1 translations when compared to those who learn vocabulary using L2 definitions?

2) Do students who learn vocabulary using $L 1$ translations prefer a bilingual or monolingual approach?

3) Is performance superior among students who take part in an L1 pre-listening activity when compared to those who take part in an L2 activity?

4) Do L1 translations help students achieve higher scores on a listening comprehension test?

5) What differences are there between higher and lower level students?

\section{Results}

\subsection{Listening Comprehension Test Performance}

Analysis of variance (ANOVA) was performed to determine whether or not there were any interaction effects related to the students' L1 use; descriptive statistics for the listening comprehension test scores are shown in Tables 1-6. The results indicate that students who adopted a bilingual rather than monolingual approach exhibited seemingly superior performance; nevertheless, the differences between them were statistically insignificant. As for the higher level (upper-intermediate) groups, students in Class 1 continuously outperformed those in Class 2, whose activity did not involve L1 use. Regarding the lower level (intermediate) groups, Table 5 shows that students in Class 3 outperformed those in Class 4 (the mean scores were 6.273 and 5.833 for Classes 3 and 4, respectively). However, Table 4 indicates that students in Class 4, who used only their L2, outperformed those in Class 3 on two tests (i.e., Tests 1 and 2), whereas students in Class 3 scored higher only once on Test 3. 
Table 1. Descriptive statistics for listening comprehension tests (upper-intermediate classes)

\begin{tabular}{lllll}
\hline Test & Class & $n$ & $M$ & $S D$ \\
\hline 1 & 1 & 24 & 6.833 & 1.863 \\
& 2 & 24 & 6.375 & 1.703 \\
2 & 1 & 24 & 7.458 & 2.598 \\
& 2 & 24 & 6.875 & 2.455 \\
3 & 1 & 24 & 8.875 & 1.715 \\
& 2 & 24 & 7.083 & 2.326 \\
\hline
\end{tabular}

Note. Full score $=12$. Classes 1 and 2 used a bilingual and monolingual approach, respectively.

Table 2. ANOVA results: means for factor A (upper-intermediate classes)

\begin{tabular}{lll}
\hline Class & $n$ & $M$ \\
\hline 1 & 72 & 7.722 \\
2 & 72 & 6.778 \\
\hline
\end{tabular}

Note. Full score $=12$. A1 $=$ Class 1 and $\mathrm{A} 2=$ Class 2 for Factor A; B1=Test $1, \mathrm{~B} 2=$ Test 2 , and $\mathrm{B} 3=$ Test 3 for Factor B .

Table 3. ANOVA results for upper-intermediate classes

\begin{tabular}{llllll}
\hline Source & SS & $d f$ & $M S$ & $F$ & $p$ \\
\hline Factor A & 32.1111111 & 1 & 32.1111111 & 4.078 & 0.0493 \\
Error [S(A)] & 362.2222222 & 46 & 7.8743961 & & \\
\hline
\end{tabular}

Note. $\mathrm{A} 1=$ Class 1 and $\mathrm{A} 2=$ Class 2 for Factor $\mathrm{A}$.

Table 4. Descriptive statistics for listening comprehension tests (intermediate classes)

\begin{tabular}{lllll}
\hline Test & Class & $n$ & $M$ & $S D$ \\
\hline 1 & 3 & 22 & 5.182 & 2.249 \\
& 4 & 22 & 5.227 & 1.444 \\
2 & 3 & 22 & 5.500 & 2.017 \\
& 4 & 22 & 6.045 & 1.609 \\
3 & 3 & 22 & 8.136 & 2.634 \\
& 4 & 22 & 6.227 & 2.235 \\
\hline
\end{tabular}

Note. Full score $=12$. Classes 3 and 4 used a bilingual and monolingual approach, respectively.

Table 5. ANOVA results: means for factor A (intermediate classes)

\begin{tabular}{lll}
\hline Class & $n$ & $M$ \\
\hline 3 & 66 & 6.273 \\
4 & 66 & 5.833 \\
\hline
\end{tabular}

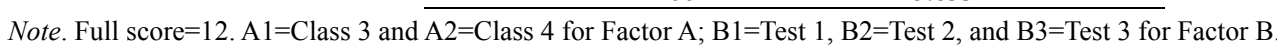

Table 6. ANOVA results for intermediate classes

\begin{tabular}{llllll}
\hline Source & SS & $d f$ & $M S$ & $F$ & $p$ \\
\hline Factor A & 6.3712121 & 1 & 6.3712121 & 1.200 & 0.2795 \\
Error [S(A)] & 222.9242424 & 42 & 5.3077201 & & \\
\hline
\end{tabular}

Note. $\mathrm{A} 1=$ Class 3 and $\mathrm{A} 2=$ Class 4 for Factor $\mathrm{A}$.

\subsection{Follow-up Survey}

After the experiments, participants were asked to respond to a two-item survey designed to obtain additional information. First, students who had adopted a bilingual approach responded to the following statement on a five-point Likert-type scale ranging from 1 (strongly disagree) to 5 (strongly agree):

My assigned pre-listening activity was helpful in understanding the spoken texts and improved my performance on the listening comprehension tests. As a result, I would like to learn vocabulary items using my L1 (i.e., Japanese translations).

Those who took a monolingual approach responded to the following statement:

My assigned pre-listening activity was helpful in understanding the spoken texts and improved my 
performance on the listening comprehension tests. As a result, I would like to learn vocabulary items using my L2 (i.e., English definitions).

Students then answered the following question:

When you listen to questions during a listening comprehension test, do you prefer to hear only English (L2), or do you need a Japanese (L1) translation?

The questionnaires were presented to students in Japanese; their English translations are provided in Appendix B. Participants' responses are summarized in Tables 7-12.

As shown in Tables 7 and 9, higher level students were more inclined to consider their assigned pre-listening activity helpful. Tables 7 and 9 also reveal that, for both levels, those who adopted a monolingual approach were more likely to be satisfied with their assigned pre-listening activity. No students who adopted a monolingual approach perceived their assigned activity to be unhelpful (see Tables 8 and 10).

Table 7. Descriptive statistics for question 1 (upper-intermediate classes)

\begin{tabular}{llll}
\hline Class & $n$ & $M$ & $S D$ \\
\hline 1 & 24 & 4.042 & 0.934 \\
2 & 24 & 4.292 & 0.735 \\
\hline
\end{tabular}

Note. Classes 1 and 2 used a bilingual and monolingual approach, respectively.

Table 8. Responses to question 1 (upper-intermediate classes)

\begin{tabular}{lllll}
\hline & Class 1 & & Class 2 & \\
Likert-type score scale & $n$ & $\%$ & $N$ & 45.8 \\
\hline 5 (strongly agree) & 8 & 33.3 & 11 & 37.5 \\
4 (agree) & 11 & 45.8 & 9 & 16.7 \\
3 (undecided) & 4 & 16.7 & 4 & 0.0 \\
2 (disagree) & 0 & 0.0 & 0 & 0.0 \\
1 (strongly disagree) & 0 & 4.2 & 0 & 100.0 \\
Total & 24 & 100.0 & 24 & \\
\hline
\end{tabular}

Table 9. Descriptive statistics for question 1 (intermediate classes)

\begin{tabular}{llll}
\hline Class & $n$ & $M$ & $S D$ \\
\hline 3 & 22 & 3.500 & 1.234 \\
4 & 22 & 3.864 & 0.694 \\
\hline
\end{tabular}

Note. Classes 3 and 4 used a bilingual and monolingual approach, respectively.

Table 10. Responses to question 1 (intermediate classes)

\begin{tabular}{lllll}
\hline Likert-type score scale & Class 3 & & Class 4 & \\
\hline 5 (strongly agree) & $n$ & $\%$ & $N$ & $\%$ \\
4 (agree) & 6 & 27.3 & 4 & 18.2 \\
3 (undecided) & 5 & 22.7 & 11 & 50.0 \\
2 (disagree) & 7 & 31.8 & 7 & 31.8 \\
1 (strongly disagree) & 2 & 9.1 & 0 & 0.0 \\
Total & 2 & 9.1 & 0 & 0.0 \\
\hline
\end{tabular}

Question 2 asked students whether they preferred to hear only English (L2) when listening to questions, or a translation into Japanese (L1) as well. In all four classes, more than half of the participants preferred to hear only English (see Tables 11 and 12). This tendency was stronger in the lower level (intermediate) classes. For example, in both Classes 3 and 4, more than $60 \%$ of the students preferred to hear English only. These results are generally in agreement with Tables 1 and 4. In fact, lower level (intermediate) students who adopted a monolingual approach outperformed their bilingual counterparts on two tests; however, for the higher level (upper-intermediate) classes, students in Class 2 never scored higher than those in Class 1, who applied a bilingual approach. 
Table 11. Responses to question 2 (upper-intermediate classes)

\begin{tabular}{lllll}
\hline & Class 1 & & Class 2 & \\
& $n$ & $\%$ & $n$ & $\%$ \\
\hline Both L1 and L2 & 9 & 37.5 & 10 & 41.7 \\
Only L2 & 13 & 54.2 & 14 & 58.3 \\
Undecided & 2 & 8.3 & 0 & 0.0 \\
Total & 24 & 100.0 & 24 & 100.0 \\
\hline
\end{tabular}

Table 12. Responses to question 2 (intermediate classes)

\begin{tabular}{lllll}
\hline & Class 3 & & Class 4 & \\
& $n$ & $\%$ & $n$ & $\%$ \\
\hline Both L1 and L2 & 4 & 18.2 & 4 & 18.2 \\
Only L2 & 14 & 63.6 & 15 & 68.2 \\
Undecided & 4 & 18.2 & 3 & 13.6 \\
Total & 22 & 100.0 & 22 & 100.0 \\
\hline
\end{tabular}

\section{Discussion and Conclusion}

This study has illustrated some differences between monolingual and bilingual approaches when administering a listening comprehension test in the EFL classroom. Indeed, the participants were more likely to prefer a monolingual approach. For example, the follow-up survey results show that the mean scores for students who preferred a monolingual approach were 4.292 and 3.864 among higher and lower level students, respectively. In contrast, the mean scores for students who preferred a bilingual approach were 4.042 and 3.500 for higher and lower level students, respectively (see Tables 7 and 9). This finding is surprising given that the participants achieved higher performance when using a bilingual method, particularly among higher level students, whose mean scores on the listening comprehension tests were 7.722 and 6.778 for a bilingual and monolingual approach, respectively (see Table 2).

Various factors might have affected the aforementioned results, including the listening materials that were used (i.e., TOEIC L\&R), which are monolingual in their approach and familiar to the participants. The TOEIC L\&R is a high-stakes examination in Japan, and thus first-year students at the university are given ample opportunities to prepare for it in order to achieve the highest possible scores. Likewise, the textbook used by participants in their General English classes contains TOEIC L\&R exercises, and teachers have students work on these exercises in class. Consequently, it is likely that their anxiety levels were relatively low during the experiment. Additionally, first-year students are required to take a course named Oral English, which is taught by a native speaker of English. Therefore, it can be assumed that the participants were accustomed to hearing English despite being native speakers of Japanese.

The previously mentioned factors possibly contributed to the participants' inclination toward a monolingual approach. If they had not been accustomed to monolingual testing or hearing English, their perceptions might have been different. Indeed, this view is supported by three students' opinions. Two students in Class 1 and one in Class 3 voluntarily shared their feelings regarding L1 use. One upper-intermediate student said, "I think it is strange to hear a Japanese translation during a test, since we are only allowed to hear English in real testing situations." Another upper-intermediate student confessed that he does not want to hear Japanese, because he strives not to rely on it when studying English. An intermediate student made a similar comment and said, "Hearing a Japanese translation discourages me, because I want to think in English."

One issue remains unresolved, however. This research has indicated that higher level students were less likely to prefer a monolingual approach. This result contradicts previous studies. Prior research generally indicates that using an L1 is more beneficial for lower level students when compared to their higher level counterparts. For example, none of the lower level students in Wen and Johnson's (1997) study considered L1 translations harmful to their L2 learning, although higher level students felt that using an L1 would hinder their progress. Moreover, using L1 translations is also a more attractive and easier method for teachers. Atkinson (1993) argued that, for most teachers in most settings, teaching entirely in students' L2 is "simply too tall an order" (p. 3). As mentioned previously, using students' L1 is a "time-saving device" (Harbord, 1992, p. 353), and also an "attractive short cut" when teachers share an L1 with their students (Alroe \& Reinders, 2015, p. 54).

There are several possible reasons for the present study's results. First, the participants were all engineering students, and their major might have affected their preferences in some manner. Liao's (2006) study revealed that 
both English proficiency and academic major caused significant differences in students' beliefs about L1 translations. Liao categorized participants according to whether or not they were foreign language majors. He found that foreign language majors tended to have negative beliefs about using L1 translations, whereas non-foreign language majors did not. The present study did not compare engineering students with students majoring in other subjects; thus, I cannot make a definitive statement concerning this matter. However, it might be possible to infer from Liao's study that engineering students, both in his study and the present one, did not possess negative beliefs regarding L1 use because they were not foreign language majors. If substantiated, such a presumption would also contradict the present study's results. This issue should therefore be investigated further.

Second, it might be that the higher level students in the present study used L1 translations in a different manner than the lower level students. To put it differently, higher level students may have sought emphatic understanding of a given word, whereas their lower level counterparts were satisfied with a more basic understanding. Liao (2006) pointed out that proficient and less proficient learners had "different understandings of translation and how it should be used in learning English" (p. 208). Less proficient learners in Liao's study translated word by word, whereas proficient learners used L1 translations only when necessary.

Several limitations of this study must be highlighted. First, a multiple-choice listening comprehension test was used, and thus some of the lower level students might have answered questions simply by guessing. It is apparent that L1 translations helped higher level students perform better on the listening comprehension tests. Tables 1 and 2 revealed that students in Class 1 consistently outperformed those in Class 2. In contrast, it is not clear that using L1 translations was helpful for lower level students. Table 5 showed that the mean scores of Class 3 were higher than those for Class 4; however, Table 4 revealed that students in Class 3 only outperformed those in Class 4 once. Hence, there is not conclusive evidence that adopting a bilingual approach helps lower level students to achieve higher performance.

Furthermore, participants were tested just three times; as such, it might have been prudent to test them several more times in order to reach a more definitive conclusion. Likewise, students in Classes 1 and 3 took a wholly bilingual approach, whereas those in Classes 2 and 4 adopted a wholly monolingual approach. Consequently, they did not have an opportunity to compare two types of pre-listening activities. Their perceptions might have been different (1) if they had completed five listening comprehension tests after adopting a monolingual approach, followed by five additional tests using a bilingual approach; (2) if they had completed five listening comprehension tests after adopting a bilingual approach, followed by five additional tests using a monolingual approach; or (3) if they had completed 10 tests using two different types of pre-listening activities for each test in an alternating fashion. These limitations should be examined in future studies.

There are a multitude of societies and cultures worldwide. If students are heterogeneous in terms of their language backgrounds, perhaps the exclusive use of an L2 is acceptable. Prior research has generally shown that bilingual approaches may be superior when learning new vocabulary items, especially for lower level students. However, the findings of this study are not necessarily compatible with previous research. When compared to relying on L2 definitions, higher level students performed better on listening comprehension tests when learning L2 vocabulary items using L1 translations. It is nevertheless difficult to say whether learning new L2 vocabulary with L1 translations helped them perform better on the listening comprehension tests, as higher level students tended to prefer a monolingual approach (i.e., learning L2 vocabulary using L2 definitions). This tendency was even more apparent among lower level students, although their listening comprehension test performance was inconsistent. These findings contradict prior studies; hence, this is a topic that warrants further exploration.

\section{References}

Afzal, S. (2013). Using of the first language in English classroom as a way of scaffolding for both the students and teachers to learn and teach English. International Research Journal of Applied and Basic Sciences, 4(7), 1846-1854. Retrieved from http://www.irjabs.com/files_site/paperlist/r_918_130715220123.pdf

Al-balawi, F. S. (2016). The attitudes of Saudi EFL teachers about using their mother tongue in EFL classrooms. International Journal of Education and Social Science, 3(7), 51-61. Retrieved from http://www.ijessnet.com/wp-content/uploads/2016/08/5.pdf

Alroe, M. J., \& Reinders, H. (2015). The role of translation in vocabulary acquisition: A replication study. Eurasian Journal of Applied Linguistics, 1(1), 39-58. Retrieved from http://hdl.handle.net/10652/3203

Atkinson, D. (1993). Teaching in the target language: A problem in the current orthodoxy. Language Learning Journal, 8(1), 2-5. http://dx.doi.org/10.1080/09571739385200261

Chang, A. C., \& Read, J. (2008). Reducing listening test anxiety through various forms of listening support. 
TESL-EJ, 12(1), 1-25. https://doi.org/10.18806/tesl.v26i1.127

Cook, V. (2001). Using the first language in the classroom. The Canadian Modern Language Review, 57(3), 402-423. http://dx.doi.org/10.3138/cmlr.57.3.402

Edstrom, A. (2006). L1 use in the L2 classroom: One teacher's self-evaluation. The Canadian Modern Language Review, 63(2), 275-292. https://doi.org/10.3138/cmlr.63.2.275

Ellis, R. (2005). Principles of instructed language learning. System, 33(2), 209-224. http://dx.doi.org/10.1016/j.system.2004.12.006

Harbord, J. (1992). The use of the mother tongue in the classroom. ELT Journal, 46(4), 350-355. http://dx.doi.org/10.1093/elt/46.4.350

Joyce, P. (2015). L2 vocabulary learning and testing: The use of L1 translation versus L2 definition. The Language Learning Journal. http://dx.doi.org/10.1080/09571736.2015.1028088

Liao, P. (2006). EFL learners' beliefs about and strategy use of translation in English learning. RELC Journal, 37(2), 191-215. http://dx.doi.org/10.1177/0033688206067428

Liu, J. (2008). L1 use in L2 vocabulary learning: Facilitator or barrier? International Education Studies, 8(2), 65-69. http://dx.doi.org/10.5539/ies.v1n2p65

Mahmoudi, L., \& Amirkhiz, S. (2011). The use of Persian in the EFL classroom-The case of English teaching and learning at pre-university level in Iran. English Language Teaching, 4(1), 135-140. http://dx.doi.org/10.5539/elt.v4n1p135

Nation, P. (2003). The role of the first language in foreign language learning. Asian EFL Journal, 5(2), 1-8. Retrieved from http://asian-efl-journal.com/june_2003_pn.pdf

Prince, P. (1996). Second language vocabulary learning: The role of context versus translations as a function of $\begin{array}{lllll}\text { proficiency. The Modern } & \text { Language Journal, }\end{array}$ http://doi.org/doi:10.1111/j.1540-4781.1996.tb05468.x

Shuchi, I. J., \& Islam, A. B. M. S. (2016). Teachers' and students' attitudes towards L1 use in EFL classrooms in the contexts of Bangladesh and Saudi Arabia. English Language Teaching, 9(12), 62-73. http://dx.doi.org/10.5539/elt.v9n12p62

Soulignavong, L., \& Souvannasy, B. (2009). Using L1 in teaching vocabulary to low English proficiency level students: A case study at the National University of Laos. English Language Teaching, 2(3), 186-193. http://dx.doi.org/10.5539/elt.v2n3p186

Turnbull, M. (2001). There is a role for the L1 in second and foreign language teaching, but.... The Canadian Modern Language Review, 57(4), 531-540. http://dx.doi.org/10.3138/cmlr.57.4.531

Wen, G., \& Johnson, R. K. (1997). L2 learner variables and English achievement: A study of tertiary-level English majors in China. Applied Linguistics, 18(1), 27-48. http://dx.doi.org/doi:10.1093/applin/18.1.27

\section{Appendix A}

\section{Vocabulary List}

\section{A. List for Classes 1 and 3}

1. review (動詞) よく調べる

2. budget (名詞) 予算

3. address (動詞) 対処する、取り組む

4. email (動詞) メールを送る

5. get off (動詞) 終える

6. affect (動詞) 影響を与える

7. soil (名詞) 土、土壌

8. irrigate (動詞) 水をまく、水をやる

9. harvest (名詞) 収穫、結果 
10. charge (動詞) 請求する

11. annual (形容詞) 年 1 回の、毎年恒例の

12. opening address (名詞) 開会の辞

13. sign up for (動詞) 申し込む、参加登録する

14. outgoing (形容詞)去っていく、退職する

15. from time to time (副詞) 時々

16. factory (名詞) 工場

17. publicity (名詞) 広報、宣伝

18. craftspeople (名詞) 職人、工芸家

19. perfect (動詞) 仕上げる、完成させる

20. article (名詞) 品物、品目

\section{B. List for Classes 2 and 4}

1. review (v.) inspect, examine, assess

2. budget (n.) plan, estimate, cost, funds

3. address (v.) solve, deal with

4. email (v.) send an email to

5. get off (v.) finish

6. affect (v.) influence, have an effect on

7. soil (n.) earth, ground

8. irrigate (v.) water, moisten, soak

9. harvest (n.) product, outcome

10. charge (v.) ask, demand

11. annual (adj.) once a year

12. opening address (n.) opening speech

13. sign up for (v.) register

14. outgoing (adj.) retiring, leaving

15. from time to time (adv.) sometimes

16. factory (n.) plant

17. publicity (n.) advertising, promotion

18. craftspeople (n.) artists, experts, masters

19. perfect (v.) complete, finish

20. article (n.) item, object, thing

\section{Appendix B}

\section{Follow-up Survey}

\section{A. Questionnaire for Classes 1 and 3}

This questionnaire contains a statement that might reflect your opinion concerning the pre-listening activity that you were assigned. It also contains a question regarding your preference for first language use during an English 
listening comprehension test.

First, please read the following statement and indicate whether you (1) strongly disagree, (2) disagree, (3) neither agree nor disagree, (4) agree, or (5) strongly agree:

My assigned pre-listening activity was helpful in understanding the spoken texts and improved my performance on the listening comprehension tests. As a result, I would like to learn vocabulary items using my L1 (i.e., Japanese translations).

$\begin{array}{lllll}1 & 2 & 3 & 4 & 5\end{array}$

Second, please read the following question and choose the response that best reflects your preference:

When you listen to questions during a listening comprehension test, do you prefer to hear only English (L2), or do you need a Japanese (L1) translation?

1. I prefer to hear both English and Japanese (i.e., both L1 and L2).

2. I prefer to hear English only (i.e., only L2).

3. I am undecided.

\section{B. Questionnaire for Classes 2 and 4}

This questionnaire contains a statement that might reflect your opinion concerning the pre-listening activity that you were assigned. It also contains a question regarding your preference for first language use during an English listening comprehension test.

First, please read the following statement and indicate whether you (1) strongly disagree, (2) disagree, (3) neither agree nor disagree, (4) agree, or (5) strongly agree:

My assigned pre-listening activity was helpful in understanding the spoken texts and improved my performance on the listening comprehension tests. As a result, I would like to learn vocabulary items using my L2 (i.e., English definitions).

$\begin{array}{lllll}1 & 2 & 3 & 4 & 5\end{array}$

Second, please read the following question and choose the response that best reflects your preference:

When you listen to questions during a listening comprehension test, do you prefer to hear only English (L2), or do you need a Japanese (L1) translation?

1. I prefer to hear both English and Japanese (i.e., both L1 and L2).

2. I prefer to hear English only (i.e., only L2).

3. I am undecided.

\section{Copyrights}

Copyright for this article is retained by the author(s), with first publication rights granted to the journal.

This is an open-access article distributed under the terms and conditions of the Creative Commons Attribution license (http://creativecommons.org/licenses/by/4.0/). 